\title{
INCOMPLETE ALBINO GREAT GRAY OWL IN IDAHO
}

MICHAEL B. WHITFIELD, P.O. Box 136, Driggs, ID. 83422, MONYA E. MAJ, P.O. Box 263, Tetonia, ID. 83452 and JILL KELLEY, Chippewa National Forest, Walker, MN. 56484

Occurrence of the Great Gray Owl is well documented in southeastern Idaho. ${ }^{2}$ Although recent information suggests concern over reduced observations of the Great Gray Owl in the area, ${ }^{4}$ U.S. Forest Service biologists and local researchers have documented many local nests. ${ }^{9}$ In this note we present records of an adult Great Gray Owl with almost completely white plumage that nested in southeastern Idaho over a three-year period and its offspring in two of three years.

Between 1990 and 1992 several observations of an adult white Great Gray Owl were recorded in southeastern Idaho. Summer observations in 1992 were in nesting habitat within $0.5 \mathrm{~km}$ of 1990 observations at a nest site. Based upon the consistent description and locations of these observations, they are all thought to represent the same adult owl.

On 3 May 1990 an employee of Harriman State Park in Island Park, Idaho reported seeing a Snowy Owl to the local Targhee National Forest Service District. Island Park District biologist J. Kelly confirmed that the owl was a Great Gray Owl, and documented the white bird on videotape during a 20 minute observation as the bird perched in a tree near the nest - a broken topped Douglas fir approximately $2 \mathrm{~m}$ high. This white owl was observed with a normally coloured adult Great Gray Owl, which delivered a pocket gopher sized prey item to one of two gray owlets seen in the nest area. The white adult Great Gray Owl and a fledged juvenile were seen in early July near an active Bald Eagle nest approximately $1.5 \mathrm{~km}$ south of the Great Gray nest. The following winter, two Forest Service employees reported seeing a large white owl near State Highway 20 approximately $14.5 \mathrm{~km}$ from the nest area. The nest area was searched in spring 1991, but no owls were located. The original nest tree had fallen.

On 13 and 21 June 1992, an adult white Great Gray Owl and one fledged owlet of normal colour were seen approximately $0.5 \mathrm{~km}$ from the original nest area. The owlet was not examined in hand, but appeared to be the normal gray plumage. Only the one adult was observed and a nest tree was not located. We believe that size and behaviour suggest that the white adult was a male. ${ }^{1}$ In spring 1993, a normally coloured pair of Great Gray Owls nested atop a 2 $m$ high Douglas fir snag near the original nest tree. The white owl was not observed during several 1993 and 1994 searches of the areas where it was earlier located.

Figure 1 is a photograph of the white owl taken in June 1992 and illustrates the extent of albinism. Although the bird was never inspected 


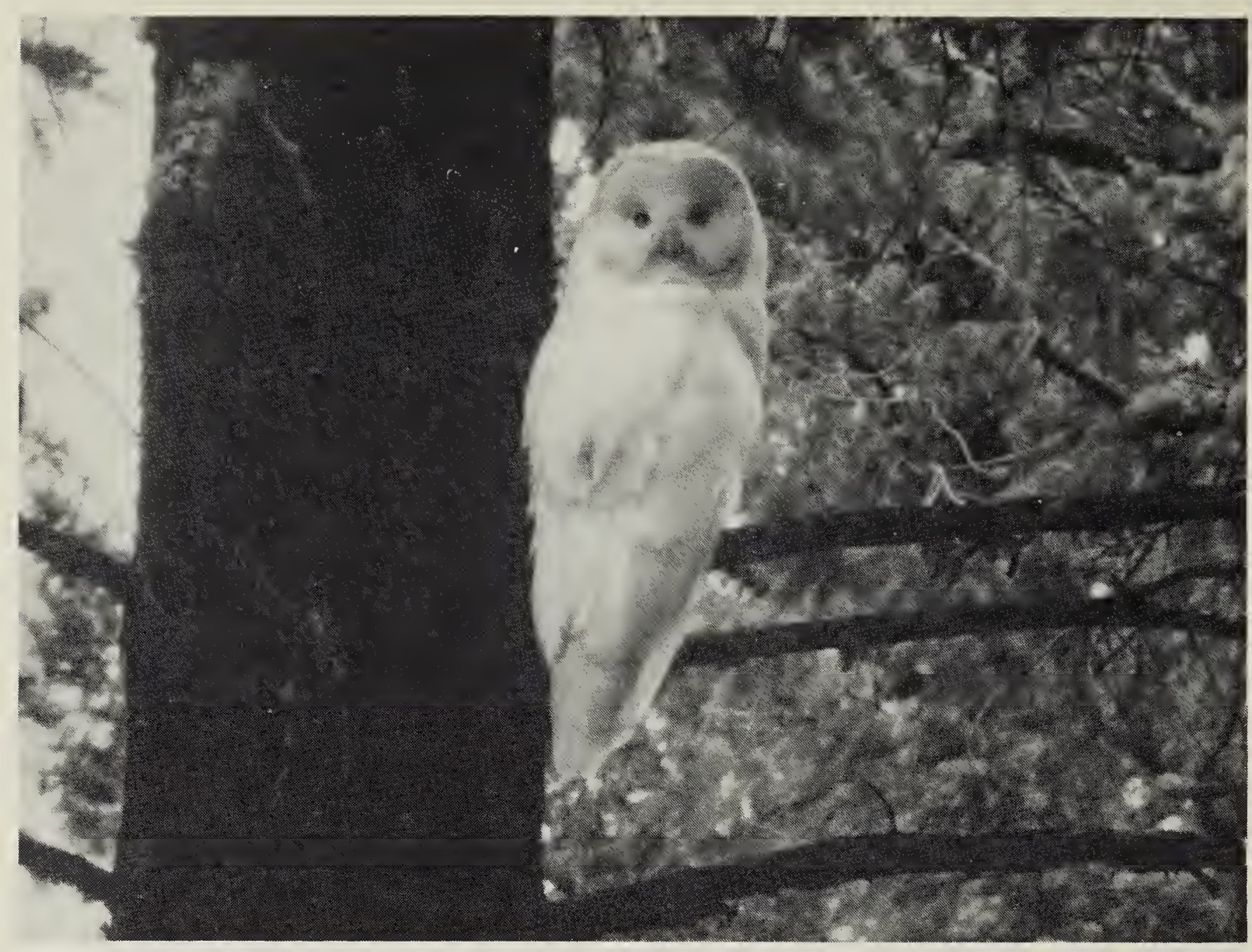

in hand, its plumage appeared to be almost totally white. The bird had no barring, lacked concentric circles around the eyes, and was entirely white except for several dark secondary feathers observed on the right wing. Secondary wing and downy feathers collected at the site were entirely white. The eyes were of normal colour with yellow irises which suggest that the bird should be considered an incomplete albino. ${ }^{3,6}$

We are aware of four published records of incomplete or partial albinism in Great Gray Owls. ${ }^{5,6,7,8}$ The first three individual reports were of owls observed in Manitoba, Canada. R. Nero (pers. comm.), who has handled over 100 Great Gray Owl skins, and T. Swen (pers. comm.), who maintains records of albinism in birds, believe that these records represent the extent of documented albinism in Great Gray Owls in North America. The latest report is of a partial albino in Finland. ${ }^{8}$
This is the first record of an incomplete albino Great Gray Owl documented in Idaho and the Northern Rockies region. The documentation (video tape, photographs, and narrative descriptions) of the observed white Great Gray Owl suggest that they were all of the same bird over three breeding seasons. This is a unique record of long-term occupation of a breeding territory by an albino owl. This note also provides a record of an adult albino Great Gray Owl producing three normally plumaged gray owlets in the two of three breeding seasons that the owls were observed.

Observation of this 'sird stimulated examination of slides taken of light coloured Great Gray Owls in 1980 by $M$. Maj on the Targhee National Forest approximately $112 \mathrm{~km}$ from the bird reported here. Close examination of these slides suggests that these Great Gray Owls were imperfect albinos. Their plumage was far 
lighter than expected, but not the striking white of the owl we reported here.

We acknowledge helpful comments on this report from Dr. Robert W. Nero.

1. BULL, E.L., M.G. HENJUM, and R.S. Rohweder. 1989. Reproduction and mortality of great gray owls in Oregon. Northwest Sci. 63:38-42.

2. FRANKLIN, A.B. 1987. Breeding biology of the great gray owl in southeastern Idaho and northwestern Wyoming. M.Sc. Thesis, Humboldt State University, Arcata, CA. 82 pp.

3. GROSS, A.O. 1965. The incidence of albinism in North American birds. Bird Banding 36:67-71.

4. GROVES, C. and E. ZEHTNER. 1990. Distribution and status of great gray owls (Strix nebulosa) on the Targhee National Forest, 1989. Coop. Challenge Cost Share Project. Targhee National Forest and Idaho Dept. of Fish and Game. 62 pp.

5. HOLLAND, G. 1991. Second albino great gray owl sighted in Manitoba. Blue Jay 49:32.

6. NERO, R.W. 1991. White great gray owl. Blue Jay 49:31.

7. SCRIVEN, R. 1984. A note on albinism in the great gray owl. Blue Jay 42:173-174.

8. WANDERS, I. 1994. Albino great gray owl in Finland. Blue Jay 52:228.

9. WHITFIELD, M.B., M.E. MAJ, M. GAFFNEY, and M. GEBHART. 1995. Monitoring of great gray owls, preliminary studies, Targhee National Forest and Teton Valley, Idaho/Wyoming. Targhee National Forest Report. Driggs, Idaho. 55 pp.

In the succession, pioneer species are the sprinters, old-forest species the long-distance runners. The violent changes and a clearing of space bring all the species briefly to the same starting line. The sprinters dash ahead, but the prolonged race goes to the marathoners. Together the two classes of specialists create a complex mosaic of vegetation types across the forest which, by regular tree falls and landslides, is forever changing. If square kilometers of space are mapped over decades of time, the mosaic turns into a riotous kaleidoscope whose patterns come and go and come again. A new marathon is always beginning somewhere in the forest. The percentages of successional vegetation types are consequently more or less in a steady state, from earliest pioneer species through various mixes of pioneer and deep-forest trees to stands of the most mature physiognomy. Wilson, E.O. 1992. The diversity of life. W.W. Norton and Company, New York. 424 pp. 